\title{
Effect of Kaolin Application with Well-Irrigated and Water- Stress on Some Growth Parameters, Yield and Fruit Quality of "Le Conte" Pear Trees
}

\author{
Rehab M. Awad \\ Plant Production Dep., Faculty of Agriculture (Saba Bacha), University of Alexandria \\ Egypt.Contact e-mail: rehab17menna@yahoo.com
}

\begin{abstract}
This experiment carried out during 2012 and 2013 experimental seasons on "Le-Conte" pear trees. The Kaolin was applied on the canopy surface of trees in well-irrigated and water stress conditions at the beginning of growth, after fruit set and 4 weeks before the commercial harvest as follows: Well-Irrigated Control (WIC), Well-Irrigated $+1 \%$ Kaolin (WI1K), Well-Irrigated $+3 \%$ Kaolin (WI3K), Well-Irrigated $+5 \%$ Kaolin (WI5K), Well-Irrigated $+7 \%$ Kaolin (WI7K), Stress-Irrigated Control (SIC), Stress-Irrigated $+1 \%$ Kaolin (SI1K), StressIrrigated $+3 \%$ Kaolin (SI3K), Stress-Irrigated $+5 \%$ Kaolin (SI5K) and Stress-Irrigated $+7 \%$ Kaolin (SI7K). Data indicated that all well and stress irrigation treatments plus spraying Kaolin tended to increase shoot length as compared with controls (WIC and SIC). Moreover, SI5K and SI3K treatments gave the highest significant value for the shoot thickness. WI3K, WI5K and SI5K treatments gave the highest significant value in leaf area. Also, SI5K, SI3K and SI7Ktreatments significantly increased fruit set percentage and decreased fruit drop percent compared to all well treatments, SI1K and the two controls (WIC and SIC) during both growing seasons. Furthermore, all well irrigation water with kaolin treatments increased average fruit weight as compared with stress irrigation water treatments, while all stress irrigation water with kaolin treatments increased number of fruits per tree as compared with well irrigation water treatments as well as control treatments during both seasons of the study. Also, SIC treatment gave the highest significant T.S.S percent compared with well irrigation treatments and WIC. Stress irrigation treatments decreased acidity percent fruit content as compared with well irrigation treatments, while all kaolin concentrations showed no effect on it. At the meantime, all stress treatments especially, SI7K increased vitamin content, as compared with WIC and SIC. Also, it was found that well irrigated increased N, P and K percentages in "Le-conte" pear leaf as compared with stress water treatments.
\end{abstract}

Keywords: pear, well and stress irrigated, kaolin, vegetative growth, yield and fruit composition.

\section{INTRODUCTION}

Regulated deficit irrigation (RDI) is the practice of using irrigation to maintain plant water status within prescribed limits of deficit with respect to maximum water potential for a prescribed part or parts of the seasonal cycle of plant development (Kriedemann and Goodwin, 2003). RDI results in higher canopy light transmission (Shellie, 2006) that may lead to undesirable fruit exposure and sunburn in warm production regions with high solar radiation (Tararaet al., 2008 and Wample, 1996). The conventional way of reducing plant water deficits is irrigation, as Le Conte pear trees are grown extensively with poor supplies of water during a drought; extensive irrigation is not only uneconomical but also impracticable.

Dropping of fruits during June month and before harvesting due to water deficits and high temperature considers a serious problem and the losses are usually of a very high magnitude. Therefore, during a drought the only means of reducing plant water deficits in trees is by using antitranspirants (Davenport et al., 1972). 
The great benefits of various antitranspirants for flowering, checking fruit drop as well as improving the yield quantitively and qualitatively of different fruit trees have fascinated pomologists and promoted much of the modern researches in this direction (Abou- Khaledet al., 1970; Davenport et al., 1974; Yang, 1995; Glenn et al., 2001; Layne et al., 2002; Green et al., 2003; Glenn et al., 2003; Jifon and Syvertsen, 2003; Abd El- Kader et al., 2006; Salehand ElAshry, 2006; Wand et al., 2006; and Alyet al., 2010). Environmental dusts and particular coverings on plants generally reduce photosynthesis and productivity due to leaf shading and interference with stomata activity. A wide range of minerals are available but kaolin offer low cost, safety profile, low absorption, particle size, dispensability in water and general commercial availability needed for agriculture use (Rosatiet al., 2006). Kaolin cools tissues and protects plants from extreme heat and ultraviolet radiation by increasing leaf reflectance and reducing transpiration rate (Nakano and Uehara, 1996 and Glenn et al., 2010).

It appears that applying a reflective coating to plants under water stress provides more benefit in reducing the heat load than reduction in potential photosynthesis. Also, it was expected that net radiation was reduced, suggesting a potential reduction in transpiration and water use (Glenn et al., 2001). Most of the early work in this area has been found to improve yield, fruit color and size, as well as the instantaneous rate of net photosynthesis of leaves (Glenn et al., 1999; Showler, 2002; Thomas et al., 2004 and Rosatiet al., 2006). Furthermore, kaolin improved net photosynthesis and stomatal conductance in citrus at midday but not in the morning (Jifon and Syvertsen, 2003) whereas no effect was found on pecan (Lombardiniet al., 2004). There have been reports of delayed maturation in some trials (Glenn et al., 2001). However, at high temperature, rate of net photosynthesis may be more limited by the heat stress than by low light so that the reduction in leaf temperature, induced by the kaolin film, could more than compensate for the negative effect of reduced light (Glennet al., 2003). It can be expected that, the kaolin applications reduced leaf temperature, reduced the water require for trees under stressed- water apple trees (saving water irrigation), may be increased the yield and improve the quality of fruits and prolonged the shelf life of fruits after harvesting.

The objective of the present study was to investigate the effect of kaolin film applications in well and stress water on Le-Conte pear trees on vegetative growth, fruit setting, yield and yield components. So the results can be used to develop a pear irrigation guide to conserve water usage in a semi-arid climate.

\section{MATERIALS AND METHODS}

This experiment was carried out during two consecutive seasons at 2012 and 2013 on "Le-Conte" pear trees (Pyrus communisx Pyrus serotinia L.). The trees were 8 years old, budded on Pyrus commun is rootstock spaced at $5 \times 4$ and grown on sandy loam soil in a private orchardat Al- Nubaria region, Behira government. Trees were trainedto the central leader system.Soil samples were, randomly, taken from two depths $(0-30 \mathrm{~cm}$ and $30-60 \mathrm{~cm})$ prior to initiating of the experiment and analyzed for physical and chemical properties. A randomized complete block design was used in this trial using five trees for 
each treatment.Pear orchard was divided into well-irrigated as required in the area and the other was done under water stress treatments.

The treatment of well-irrigated was irrigated with fertigated system carried out in the farm (Well irrigation), while the treatment of water stress was provided an amount of supplemental water that met either $100 \%$ of estimated crop evapotranspiration(ETc) throughout the growing season then reduced percentage of ETc beginning shortly in spring irrigated at $70 \%$ from the practical irrigation (Stress irrigation). The two water irrigation regimes were equivalent to $100 \%$ and $70 \%$ of crop evaporation respiration $(\mathrm{ETc})$ were determined by using the Penman Monteith model according to Allen et al. (1998) equation:

Crop evapotranspiration $(\mathrm{ETc}), \mathrm{mm} / \mathrm{day}=\mathrm{ET}_{\mathrm{o}} \mathrm{x} \mathrm{K}_{\mathrm{c}}$

Which ETo: Potential evapotranspiration

$\mathrm{K}_{\mathrm{c}}$ : Crop coefficient

Fifty trees nearly uniform as possible in growth vigor and productivity were chosen for each water treatments. The trees were subjected to fertigation system used in the practical field. Other cultural practices were applied in a manner consistent with those of commercial pear with orchards. Four rates of kaolin were applied for both water irrigation systems with an air- blast sprayer and control treatment.The reflective films applied on the canopy surface of trees in well-irrigated andwater stress conditions are as follows:

1- Well-Irrigated Control (WIC).

2- Well-Irrigated $+1 \%$ Kaolin clay (WI1K).

3- Well-Irrigated $+3 \%$ Kaolin clay (WI3K).

4- Well-Irrigated $+5 \%$ Kaolin clay (WI5K).

5 - Well-Irrigated $+7 \%$ Kaolin clay (WI7K).

6- Stress-Irrigated Control (SIC).

7- Stress-Irrigated $+1 \%$ Kaolin clay (SI1K).

8- Stress-Irrigated $+3 \%$ Kaolin clay (SI3K).

9- Stress-Irrigated $+5 \%$ Kaolin clay (SI5K).

10- Stress-Irrigated $+7 \%$ Kaolin clay (SI7K).

Reflective film (Kaolin) was applied at the beginning of growth, after fruit set and 4 weeks before the commercial harvest date using Tween 20 (1\%) as a surfactant.Soil analysis was carried prior and the end of experiment in different depths (Table 1). Water quality used in experimental study is presented in Table (2). 
Table (1): Physical and chemical properties of experimental orchard soil

\begin{tabular}{|c|c|c|c|c|c|c|c|c|c|c|c|c|c|}
\hline \multirow{2}{*}{$\begin{array}{c}\text { Depths } \\
\text { (cm) }\end{array}$} & \multirow{2}{*}{$\begin{array}{c}\text { Sand } \\
\%\end{array}$} & \multirow{2}{*}{$\begin{array}{c}\text { Silt } \\
\%\end{array}$} & \multirow{2}{*}{$\begin{array}{c}\text { Clay } \\
\%\end{array}$} & \multirow{2}{*}{\multicolumn{2}{|c|}{$\mathrm{pH} \begin{array}{r}\mathrm{EC} \\
\text { (ds/m) }\end{array}$}} & \multicolumn{3}{|c|}{ Anions (meq / L) } & \multicolumn{5}{|c|}{ Cations ( meq / L) } \\
\hline & & & & & & $\mathrm{HC}_{3}^{-}$ & $\mathrm{CL}^{-}$ & $\mathrm{SO}_{4}^{-}$ & $\mathrm{NH}_{4}^{+}$ & $\mathrm{Ca}^{++}$ & $\mathrm{Mg}^{++}$ & $\mathrm{Na}^{+}$ & $\mathrm{K}^{+}$ \\
\hline $0-30$ & 70.3 & 10.1 & 18.6 & 7.6 & 0.78 & 12.9 & 4.2 & 4.27 & 0.06 & 5.75 & 4.0 & 6.7 & 0.220 \\
\hline $30-60$ & 68.2 & 11.5 & 17.7 & 7.7 & 0.91 & 13.2 & 4.3 & 3.59 & 0.09 & 4.43 & 3.29 & 6.04 & 0.042 \\
\hline
\end{tabular}

Table (2): Water quality used in experimental study

\begin{tabular}{c|cc|c|c|c|c|c|c|c|c}
\hline \multirow{2}{*}{ SAR } & \multirow{2}{*}{$\begin{array}{c}\mathrm{EH} \\
\mathrm{EC}\end{array}$} & \multicolumn{3}{|c|}{ Anions (meq / $\mathrm{L})$} & \multicolumn{4}{c}{ Cations ( meq / $\mathrm{L}$} \\
\cline { 4 - 11 } & & & $\mathrm{HCO}_{3}^{-}$ & $\mathrm{CL}^{-}$ & $\mathrm{SO}_{4}^{-}$ & $\mathrm{NH}_{4}^{+}$ & $\mathrm{Ca}^{++}$ & $\mathrm{Mg}^{+}$ & $\mathrm{Na}^{+}$ & $\mathrm{K}^{+}$ \\
\hline 10.10 & 7.1 & 5.62 & 12.20 & 75.14 & 4.27 & 0.06 & 5.75 & 8.0 & 2.0 & 0.22 \\
\hline
\end{tabular}

The following parameters were measured:

Shoot length $(\mathbf{c m})$ : In the spring of each season, 20 non -fruiting shoots of spring cycle were tagged at constant height and at all direction of each tree. In October, the average length of tagged shoots was measured.

Shoot diameter (cm): At late October in both seasons, shoot thickness for twenty shoots was measured by hand caliber.

Leaf area (cm2): Leaf area was examined during the second half of August on fully developed mature leaves by portable area meter LI .COR model LI-3000 A.

Fruit set and drop percentages: In the spring, four branches were chosen from each tree and marked. The number of flowers, number of fruits on these branches and the remained fruits on these branches were counted then the fruit set and fruit drop percentages were calculated according to the equation. Sixty days after flowering, fruit set percentage was calculated in the same sequence mentioned above for the initial fruit set percentage according to this formula:

$$
\text { Fruit set }(\%)=\frac{\text { No. of fruit lets }}{\text { No. of opened flowers }} \times 100
$$

Fruit drop (\%): was calculated by counting the number of dropping fruits from the middle of June till the commercial harvesting time under experimental conditions (Middle of August), then expressed as a percentage from the whole number of fruits remained on the tree at the middle of June according to this formula:

Fruit drop $(\%)=$ No. of dropped fruits $\times 100$

No. of set fruit lets

Average fruit weight ( $g /$ fruit), fruit samples were weighted and the average fruit weight for each replicate was calculated. 
No. fruits/tree, Weight of fruits/tree: At harvest time, yield of each treatment was recorded as yield weight/tree by the multiplying number of fruits $\times$ average weight of fruit.

Fruit firmness: was expressed as (pound / Inch ${ }^{2}$ ) according to (Magness and Taylor, 1925). Flesh firmness was measured in two opposite sides of the fruit using Magness Taylor pressure tester.

Regarding chemical fruit characteristics, samples of 10 fruits from each replicate tree i.e. 30 fruits for each of the applied treatment was picked randomly at harvest to determine the following parameters:

Total soluble solids of fruit juice (TSS \%) was used to determine the percentage of TSS by hand refractometer.

The percentage of total acidity was determined in fruit juice according to the A.O.A.C. (1985) by titration with $0.1 \mathrm{~N}$ sodium hydroxide using phenolphthalein as an indicator and expressed as grams malic acid / 100 milliliters.

Vitamin C (Ascorbic acid): The ascorbic acid content of the juice was determined by titration with 2, 6 dichloro phenol-indo-phenol (A.O.A.C., 1985) and calculated as milli-grams per $100 \mathrm{ml}$ of juice.

Leaf elemental compositions: At the end of July of both seasons, samples of 40 leaves /tree were taken at random from the previously tagged shoots, the leaf samples were washed with tap water and distilled water, and then oven dried at $70^{\circ} \mathrm{C}$ to constant weight and then ground. To determine the leaf elemental contents, ground material of each sample was digested with sulphoric acid and hydrogen peroxide according to Evenhuis and Dewaard (1980).

In the digested material, total nitrogen and phosphorus were determined colorimetrically according to Evenhuis (1976) and Murphy and Riley (1962), respectively and potassium was determined by flame photometer. The concentrations of N, P and $\mathrm{K}$ were expressed as percent.

\section{Statistical analysis}

Results of the measured parameters were subjected to computerized statistical analysis using MSTAT package for analysis of variance (ANOVA) and means of treatments were compared using L.S.D. at 0.05 according to Snedecor and Cochran (1980). 


\section{RESULTS AND DISCUSSION \\ Vegetative growth:}

The data for both experimental seasons, regarding the effect of different treatments of well and stress irrigation and kaolin spraying on the shoot length of "Le-conte" pear trees are shown in Table (3). Data indicated that, in general well irrigated treatments increased the shoot length as compared with stress irrigation treatments. Statistical analysis showed that, WI5K and WI7K treatments caused the highest significant length in the two seasons and SIC had the lowest significant value in both experimental seasons. Furthermore, data showed that, for both experimental seasons, all well and stress irrigation treatments plus spraying Kaolin in any rates tended to increasing shoot length as compared with control treatment (WIC and SIC). No significant difference was found among SI1K, SI5K and SI7K in both seasons.

Results of the effect of different treatments on shoot thickness of "Leconte" pear trees clearly indicated that, in spite of all well irrigation with kaolin treatments under the study increased the shoot thickness of "Le-conte" pear trees during 2012 and 2013 seasons as compared with well irrigation ( control) and the difference was not big enough to be significant, except WI7K in the first season, but the stress irrigation with kaolin spraying treatments generally increased the shoot thickness as compared with well irrigation with kaolin treatments as well as control treatments in both seasons. SI5K and SI3K treatments gave the highest significant value for the shoot thickness as compared with other treatments in both seasons (Table 3).

With regard to leaf area, data indicated that WI3K, WI5K and SI5K treatments gave the highest significant value in leaf area meanwhile, control treatments (WIC and SIC) tended to decrease leaf area of "Le-conte" pear trees in both seasons (Table 3).

The same results were reported by several authors, Heron et al. (2002) on pear found that sprays of prohexadione-Ca under water regime condition reduced shoot growth and Glenn et al. (2010) on grape vines (Vitis vinifera L. cvs. 'Cabernet Sauvignon', 'Merlot', and 'Viognier') using a particle film treatment (PFT) under varying levels of applied water. Boland et al. (2000a\&b) have shown in peach that deficit irrigation can restrict root volume and that was associated with a reduction in vegetative growth and canopy transpiration demand. Cooley et al. (2004) reported, up to 17\% reduction in leaf area and $40 \%$ reduction in shoot growth in 'Cabernet Sauvignon' under deficit irrigation and Shellie (2006) reported that, an increase in 'Merlot' canopy light transmission under deficit irrigated. The reduction in gs observed in this study under deficit irrigation regimes was most likely the result of negative feedback of low plant water status. Plant water status, at any point in time, is influenced by prior water status conditions that may have altered root capacity for water uptake, xylem hydraulic conductivity, non-hydraulic signals (Soar et al., 2004), and/or the ratio of shoot to root transpiration demand. 
Table (3): Effect of kaolin applications at well and stress irrigated pear trees on some growth parameters in 2012 and 2013 seasons

\begin{tabular}{c|cccccc}
\hline \multirow{2}{*}{ Treatments } & \multicolumn{2}{|c}{$\begin{array}{c}\text { Shoot lengt } \\
(\mathrm{cm})\end{array}$} & \multicolumn{2}{c}{$\begin{array}{c}\text { Shoot diameter } \\
(\mathrm{cm})\end{array}$} & \multicolumn{2}{c}{$\begin{array}{c}\text { Leaf } \\
\left(\mathrm{cm}^{2}\right)\end{array}$} \\
\cline { 2 - 7 } & 2012 & 2013 & 2012 & 2013 & 2012 & 2013 \\
\hline WIC & $41.36^{\mathrm{c}}$ & $40.86^{\mathrm{cd}}$ & $0.38^{\mathrm{c}}$ & $0.39^{\mathrm{c}}$ & $22.36^{\mathrm{ab}}$ & $22.98^{\mathrm{b}}$ \\
WI1K & $43.23^{\mathrm{c}}$ & $44.65^{\mathrm{bc}}$ & $0.39^{\mathrm{c}}$ & $0.41^{\mathrm{c}}$ & $23.12^{\mathrm{ab}}$ & $23.23^{\mathrm{b}}$ \\
WI3K & $45.12^{\mathrm{bc}}$ & $46.13^{\mathrm{b}}$ & $0.39^{\mathrm{c}}$ & $0.42^{\mathrm{c}}$ & $25.23^{\mathrm{a}}$ & $26.12^{\mathrm{a}}$ \\
WI5K & $52.23^{\mathrm{a}}$ & $50.33^{\mathrm{a}}$ & $0.42^{\mathrm{bc}}$ & $0.43^{\mathrm{c}}$ & $25.23^{\mathrm{a}}$ & $26.85^{\mathrm{b}}$ \\
WI7K & $48.13^{\mathrm{b}}$ & $49.74^{\mathrm{a}}$ & $0.45^{\mathrm{ab}}$ & $0.46^{\mathrm{bc}}$ & $24.12^{\mathrm{ab}}$ & $25.25^{\mathrm{ab}}$ \\
SIC & $38.25^{\mathrm{d}}$ & $39.22^{\mathrm{d}}$ & $0.46^{\mathrm{ab}}$ & $0.52^{\mathrm{ab}}$ & $21.86^{\mathrm{b}}$ & $22.82^{\mathrm{b}}$ \\
SI1K & $42.12^{\mathrm{c}}$ & $43.86^{\mathrm{bc}}$ & $0.47^{\mathrm{ab}}$ & $0.53^{\mathrm{ab}}$ & $23.01^{\mathrm{ab}}$ & $23.20^{\mathrm{b}}$ \\
SI3K & $43.23^{\mathrm{c}}$ & $41.29^{\mathrm{cd}}$ & $0.49^{\mathrm{a}}$ & $0.56^{\mathrm{a}}$ & $24.02^{\mathrm{ab}}$ & $23.23^{\mathrm{b}}$ \\
SI5K & $45.12^{\mathrm{bc}}$ & $42.92^{\mathrm{bcd}}$ & $0.50^{\mathrm{a}}$ & $0.58^{\mathrm{a}}$ & $25.28^{\mathrm{a}}$ & $26.36^{\mathrm{a}}$ \\
SI7K & $44.32^{\mathrm{bc}}$ & $42.83^{\mathrm{bcd}}$ & $0.48^{\mathrm{a}}$ & $0.51^{\mathrm{ab}}$ & $24.98^{\mathrm{a}}$ & $24.55^{\mathrm{ab}}$ \\
\hline
\end{tabular}

Means followed by the same letter(s) within a separate column are not significantly different at 0.05 level of probability.

\section{Fruit set and drop percentages:}

The data concerning the effect of well and stress irrigation plus spraying kaolin on the percentage of fruit set and drop of "Le-conte" pear trees during 2012 and 2013 seasons are presented in Table (4).The results showed that, spraying the trees, in general stress irrigation treatments and kaolin applied increased the percentage of fruit set and decreased the percentage of fruit drop. Statistical analysis showed that, SI5K, SI3K and SI7Ktreatments significantly increased fruit set percentage and decreased fruit drop percent compared to all well irrigated treatments, SI1K and the two controls (WIC and SIC) during both growing seasons. No significant difference was found between SI5K and SI7K in the first season for fruit set percent. The lowest significant values were obtained by WIC and WI7K in the two seasons. While, the lowest significant percent of fruit drop obtained by SI5K and SI7K and the highest significant value was obtained by WIC and WI7K in the two experimental seasons. The data also showed that, stress irrigation without applied kaolin (SIC) gave fruit set \% more than well irrigation without applied kaolin (WIC), while the reverse was true for fruit drop \% in both seasons.

The beneficial of these antitranspirants on increasing plant water potential and accelerating cell division can enhance growth characters and prevent the formation of abscission zone by increasing calcium in the proximal and distal sides of the abscission zone of the fruits was mainly attributed to their positive action on standing the various stresses surrounded the trees such as water stress and high temperature ( Davenportet al.,1972 and 1974). In the meantime, Masoud (2012) found that foliar application of the three antitranspirants namely Vapor gard, Kaolin and green miracle at 1.0 to $4.0 \%$ considerably declined preharvest fruit dropping on Hamawy apricot trees. The promoting effect of these antitranspirants on growth (Davenport et al., 1972) as well as their positive action on reducing preharvest fruit dropping surely 
reflected on enhancing the yield as number of fruits and weight ( $\mathrm{kg}$.). These results are in agreement with those obtained by Glenn et al. (2001); Green et al.(2003) and Aly et al. (2010) on apple and Masoud (2012) on apricot.

Table (4): Effect of kaolin applications at well and stress irrigated pear trees on fruit set and drop percent in 2012 and 2013 seasons

\begin{tabular}{c|cccc}
\hline \multirow{2}{*}{ Treatments } & \multicolumn{2}{|c}{ Fruit set \% } & \multicolumn{2}{c}{ Fruit drop $\%$} \\
\hline & 2012 & 2013 & 2012 & 2013 \\
\hline WIC & $8.43^{\mathrm{e}}$ & $8.63^{\mathrm{e}}$ & $91.57^{\mathrm{a}}$ & $91.37^{\mathrm{b}}$ \\
WI1K & $9.23^{\mathrm{d}}$ & $9.21^{\mathrm{d}}$ & $90.77^{\mathrm{b}}$ & $90.79^{\mathrm{cd}}$ \\
WI3K & $9.85^{\mathrm{c}}$ & $9.58^{\mathrm{c}}$ & $90.15^{\mathrm{c}}$ & $90.45^{\mathrm{d}}$ \\
WI5K & $10.12^{\mathrm{c}}$ & $9.23^{\mathrm{d}}$ & $89.88^{\mathrm{c}}$ & $90.77^{\mathrm{cd}}$ \\
WI7K & $8.21^{\mathrm{e}}$ & $8.23^{\mathrm{f}}$ & $91.79^{\mathrm{a}}$ & $91.77^{\mathrm{a}}$ \\
SIC & $9.48^{\mathrm{d}}$ & $8.96^{\mathrm{d}}$ & $90.52^{\mathrm{ab}}$ & $91.04^{\mathrm{bc}}$ \\
SI1K & $10.12^{\mathrm{c}}$ & $9.23^{\mathrm{d}}$ & $89.88^{\mathrm{c}}$ & $90.77^{\mathrm{cd}}$ \\
SI3K & $11.28^{\mathrm{b}}$ & $11.85^{\mathrm{b}}$ & $89.72^{\mathrm{d}}$ & $88.15^{\mathrm{e}}$ \\
SI5K & $12.03^{\mathrm{a}}$ & $12.23^{\mathrm{a}}$ & $87.97^{\mathrm{e}}$ & $87.77^{\mathrm{e}}$ \\
SI7K & $12.07^{\mathrm{a}}$ & $11.99^{\mathrm{b}}$ & $87.93^{\mathrm{e}}$ & $88.01^{\mathrm{e}}$ \\
\hline
\end{tabular}

Means followed by the same letter(s) within a separate column are not significantly different at 0.05 level of probability.

\section{Physical properties:}

Concerning the applying well or stress irrigation water with kaolin on the average fruit weight (g/ fruit) of "Le-conte" pear trees in 2012 and 2013 seasons, results revealed that all well irrigation water with kaolin( which show an increase in average fruit weight ( $\mathrm{g} /$ fruit) as compared with WIC and SIC in both seasons) treatments increased average fruit weight as compared with stress irrigation water treatment as well as control treatments during both seasons of the study, and that increase in fruit weight is big enough to be significant. It was noticed that WI5K treatment gave the highest average fruit weight (g/ fruit) of "Le-conte" pear trees in 2012 and 2013 seasons, meanwhile, the SIC treatments gave the lowest value of average fruit weight ( $\mathrm{g} / \mathrm{fruit}$ ) of "Leconte" pear trees in both seasons (Table 5).

Regarding the number of fruits per tree, data revealed that all stress irrigation water with kaolin treatments increased number of fruits per tree as compared with well irrigation water treatment as well as control treatments during both seasons of the study. It was noticed that SI5K treatment gave the highest significant average fruit weight ( $g$ / fruit) of "Le-conte" pear trees then SI7K and SI3K in 2012 and 2013 seasons, meanwhile, the WIC and SIC treatments (control) gave the lowest significant values of the number of fruits per tree of "Le-conte" pear in both seasons (Table 5).

As for weight of fruits/tree $(\mathrm{kg})$, it was found that, all well irrigation and stress irrigation with kaolin treatments showed an improvement in average of weight of fruits/ tree $(\mathrm{kg})$ as compared with well and stress irrigation controls in 
both seasons. Statistical analysis showed that, the highest significant value was obtained by WI5K in both seasons and followed by SI3K and SI5K and no significant difference was found between WI5K and SI5K in the second season. The lowest significant value was obtained by WIC and SIC in both seasons.

Regarding the influence of irrigation and kaolin treatments on fruit firmness of "Le- conte" pear trees during the both seasons, data showed that, all well irrigation plus kaolin tended to decreased fruit firmness of "Le- conte" pear trees during both seasons as compared with WIC. Moreover, it was noticed that increasing kaolin concentrations in well irrigated treatments led to decreased fruit firmness of "Le- conte" pear trees during the both seasons. At the same time, all stress water irrigation plus kaolin treatments increased fruit firmness of "Le- conte" pear trees during the both seasons. Generally, no significant differences were noticed among WIC, WI1K and WI3K also, no significant differences were noticed among SI3K, SI5K and SI7K treatments for effected on fruit firmness of "Le- conte" pear trees during the both seasons (Table 5).

Song et al. (2012) found that the largest berry fresh weight of grape in both years, when used water regime (35-70\% ETc or 35\% ETc treatments) and the data showed a significant decrease in berry fresh weight by 23-29\% in the 2 years.

The effect of antitranspirants on increasing calcium in the proximal and distal sides of the abscission zone of the fruits was mainly attributed to their positive action on standing the various stresses surrounded the trees such as water stress and higher temperature ( Davenport et al., 1972).David et al. (2003) in pear, there was a significant negative correlation where flesh firmness decreased as SSC increased. When data were pooled across cultivars in 1999 and regression analysis was conducted, a significant linear relationship existed between flesh firmness and SSC for both the control and film treatments, respectively. Moreover, Glenn et al. (2003) in apple found that, the kaolin applications reduced leaf temperature, reduced the water require for trees under stressed- water apple trees (saving water irrigation), may be increased the yield and improve the quality of fruits and prolonged the shelf life of fruits after harvesting. Also, Rosatiet al. (2006) showed that Kaolin applications have been used to mitigate the negative effects of water and heat stress on plant physiology and productivity with variable results, ranging from increased to decreased yields and photosynthetic rates. The mechanisms of action of kaolin applications are not clear: although the increased albedo reduces leaf temperature and the consequent heat stress, it also reduces the light available for photosynthesis, possibly offsetting benefits of lower temperature. Abd ElRhman (2010) found that all studied treatments (controlled irrigation, bagging, zinc sulphate and kaolin) had no effect on yield / tree $(\mathrm{kg})$ but seeds\% (grains)/fruit weight were reduced significantly when trees were treated with controlled irrigation, bagging, zinc sulphate and kaolin sprays. 
Table (5): Effect of kaolin applications at well and stresses irrigated pear trees on some fruit parameters in 2012 and 2013 seasons

\begin{tabular}{c|cccccccc}
\hline \multirow{2}{*}{ Treatments } & \multicolumn{3}{|c}{$\begin{array}{c}\text { Average fruit } \\
\text { weight }(\mathrm{g})\end{array}$} & \multicolumn{2}{c}{ No fruits/tree } & \multicolumn{2}{c}{$\begin{array}{c}\text { Weight of } \\
\text { fruits/tree }(\mathrm{kg})\end{array}$} & \multicolumn{2}{c}{$\begin{array}{c}\text { Fruit firmness } \\
\text { ( pound /inch }\end{array}$} \\
& 2012 & 2013 & 2012 & 2013 & 2012 & 2013 & 2012 & 2013 \\
\hline WIC & $139.23^{\mathrm{d}}$ & $137.82^{\mathrm{c}}$ & $189.24^{\mathrm{h}}$ & $178.21^{\mathrm{f}}$ & $26.30^{\mathrm{g}}$ & $24.84^{\mathrm{e}}$ & $16.23^{\mathrm{cd}}$ & $16.25^{\mathrm{bc}}$ \\
WI1K & $141.22^{\mathrm{c}}$ & $144.32^{\mathrm{b}}$ & $192.11^{\mathrm{g}}$ & $188.98^{\mathrm{e}}$ & $27.05^{\mathrm{e}}$ & $27.38^{\mathrm{c}}$ & $16.03^{\text {de }}$ & $16.12^{\mathrm{cd}}$ \\
WI3K & $143.56^{\mathrm{b}}$ & $143.36^{\mathrm{b}}$ & $196.32^{\mathrm{f}}$ & $195.24^{\mathrm{d}}$ & $28.18^{\mathrm{d}}$ & $28.03^{\mathrm{b}}$ & $16.02^{\text {de }}$ & $16.11^{\mathrm{cd}}$ \\
WI5K & $148.21^{\mathrm{a}}$ & $146.52^{\mathrm{a}}$ & $209.23^{\mathrm{e}}$ & $199.53^{\mathrm{c}}$ & $31.00^{\mathrm{a}}$ & $29.25^{\mathrm{a}}$ & $15.96^{\text {de }}$ & $15.99^{\mathrm{d}}$ \\
WI7K & $140.45^{\mathrm{c}}$ & $138.36^{\mathrm{c}}$ & $188.36^{\mathrm{h}}$ & $193.23^{\mathrm{d}}$ & $26.66^{\dagger}$ & $26.89^{\mathrm{c}}$ & $15.89^{\mathrm{e}}$ & $15.45^{\mathrm{e}}$ \\
SIC & $129.23^{\mathrm{i}}$ & $131.23^{\mathrm{f}}$ & $189.23^{\mathrm{h}}$ & $193.24^{\mathrm{d}}$ & $24.66^{\mathrm{h}}$ & $25.36^{\mathrm{d}}$ & $16.70^{\mathrm{a}}$ & $16.55^{\mathrm{a}}$ \\
SI1K & $136.25^{\mathrm{f}}$ & $133.23^{\mathrm{e}}$ & $211.21^{\mathrm{d}}$ & $201.32^{\mathrm{c}}$ & $28.81^{\mathrm{c}}$ & $26.88^{\mathrm{c}}$ & $16.63^{\mathrm{ab}}$ & $16.50^{\mathrm{a}}$ \\
SI3K & $137.89^{\mathrm{e}}$ & $135.21^{\mathrm{d}}$ & $212.32^{\mathrm{c}}$ & $208.87^{\mathrm{b}}$ & $29.27^{\mathrm{b}}$ & $28.24^{\mathrm{b}}$ & $16.35^{\mathrm{c}}$ & $16.41^{\mathrm{ab}}$ \\
SI5K & $133.25^{\mathrm{g}}$ & $136.23^{\mathrm{d}}$ & $218.24^{\mathrm{a}}$ & $213.89^{\mathrm{a}}$ & $29.09^{\mathrm{bc}}$ & $29.18^{\mathrm{a}}$ & $16.40^{\mathrm{bc}}$ & $16.33^{\mathrm{ab}}$ \\
SI7K & $130.23^{\mathrm{h}}$ & $132.22^{\text {ef }}$ & $214.22^{\mathrm{b}}$ & $211.23^{\mathrm{b}}$ & $27.91^{\mathrm{d}}$ & $28.06^{\mathrm{b}}$ & $16.41^{\mathrm{bc}}$ & $16.35^{\mathrm{ab}}$ \\
\hline
\end{tabular}

Means followed by the same letter(s) within a separate column are not significantly different at 0.05 level of probability.

\section{Chemical properties of fruits:}

Data of Table (6) revealed that, increasing rates of kaolin, gradually, decreased the content of fruits from T.S.S \% in both seasons. At the same time, in general, stress irrigation treatments increased T.S.S percentage as compared with well irrigation treatments. It was found that, SIC treatment gave the highest significant T.S.S percent compared with well irrigation treatments and WIC, while the differences among the rest treatments (stress irrigation with kaolin) were not big enough to be significant, except for SI7K in the first season. In the meantime, the lowest significant values were found in WI5K and WI7K, in the second season.

As for ,the effect of well and stress water irrigation with or without kaolin treatments, it was found that, in general, stress irrigation treatments decreased acidity percent fruit content as compared with well irrigation treatments, while all kaolin concentrations showed no effect on it. Statistical analysis of the data showed that, the highest significant value was obtained by WI1K in the first season and WIC in the second season. Meanwhile, the lowest value of acidity percent was obtained by SI7K in the first season. It is cleared from the data that, no significant differences were found among the stress irrigation treatments in the second season.

Furthermore, the data as for the effect of irrigation plus kaolin on vitamin $\mathrm{C}$ content in "Le-conte" pear fruits during 2012 and 2013 seasons showed that, stress treatments in general led to increase Vitamin content, in the meantime all kaolin concentra tions in well as well as stress irrigation treatments in both seasons, increased fruit vitamin C content as compared with WIC and SIC. While, SI7K gave the highest significant value in the two seasons. Masoud 
(2012) found that, there was a gradual promotion on fruit weight and vitamin $\mathrm{C}$ with increasing concentrations of each antitranspirants.

Regulated deficit irrigation is a significant improvement in water management for horticultural crops because it reduces irrigation water inputs while improving crop quality (Glenn et al., 2010), also it has been used with peach and pear to shift photo assimilate sinks from vegetative to reproductive growth and increase yield, fruit quality and water use efficiency (Boland et al., 1993; Chalmers et al., 1981; Johnson et al.,1992; Mitchell and Chalmers 1982; Mitchell et al., 1989; Moiana et al., 2003). On the other hand, regulated deficit irrigation in wine grapes is commonly applied during two periods to increase berry quality, water deficits early in the season, from fruit set to veraison, control berry size and reduce vine vigor ( McCarthy et al., 2002 and Keller, 2005). Water deficit early in the season or after veraison and during fruit ripening can reduce yield and vegetative development compared to full irrigation (Kriedemann and Goodwin, 2003) and can benefit berry and wine quality in different ways (McCarthy et al. 2002; Cortell et al. 2005 and Romero et al., 2010) Plant water relations were more impacted by irrigation regime than by particle film; however, vines with kaolin- particle film had the coolest leaf and canopy temperature (Glenn et al., 2010). Trees under deficit irrigation had the warmest leaf and canopy temperature.

Song et al. (2012) found that the lowest total soluble solids, highest titratable acidity, and lowest $\mathrm{pH}$ in both years of grape, when used water regime (35-70\% ETc or $35 \%$ ETc treatments) and the data showed a significant decrease in berry fresh weight by $23-29 \%$ in the 2 years.

Higher total soluble solids in grapes under water deficit could be related to the indirect effects of water stress (Koundouras et al., 2009). Also, David et al. (2003) showed that, there was a significant negative correlation where flesh firmness decreased while, total soluble solids increased in pear. Glenn et al. (2003) in apple, expected that, the kaolin applications reduced leaf temperature, reduced the water require for trees under stressed- water apple trees (saving water irrigation), may be increased the yield and improve the quality of fruits and prolonged the shelf life of fruits after harvesting. Rosati et al. (2006) showed that Kaolin applications have been used to mitigate the negative effects of water and heat stress on plant physiology and productivity with variable results, ranging from increased to decreased yields and photosynthetic rates. Abd El-Rhman (2010) found that, in pomegranate, total soluble solids, total sugar and reducing sugars and other physical and chemical measurements were increased as influenced by foliar spraying with all treatments (controlled irrigation, bagging, zinc sulphate and kaolin) in both studied seasons. Masoud (2012) worked on Hamawy apricot trees, were subjected twice to three antitranspirants namely Vapor gard, Kaolin and green miracle each at 1.0, 2.0 and $4.0 \%$ in addition, to the control treatment, and the data showed that foliar application of the three antitranspirants declined preharvest fruit dropping and total acidity percentage and improved the yield, calcium pectate $\%$ on distal and proximal sides of the abscission zone, fruit weight, total soluble solids \%, total and reducing sugars, sucrose \% and ascorbic acid comparing with the check treatment. 
Table (6): Effect of kaolin applications at well and stresses irrigated pear treeson some chemical fruit parameters in 2012 and 2013 seasons

\begin{tabular}{|c|c|c|c|c|c|c|}
\hline \multirow[t]{2}{*}{ Treatments } & \multicolumn{2}{|c|}{ TSS \% } & \multicolumn{2}{|c|}{ Acidity \% } & \multicolumn{2}{|c|}{$\begin{array}{c}\text { Vitamin C } \\
\text { (mg/100 ml juice) }\end{array}$} \\
\hline & 2012 & 2013 & 2012 & 2013 & 2012 & 2013 \\
\hline WIC & $12.23^{\mathrm{bcd}}$ & $12.36^{\mathrm{bc}}$ & $0.49^{\mathrm{ab}}$ & $0.51^{\mathrm{a}}$ & $19.10^{\mathrm{e}}$ & $19.21^{d}$ \\
\hline WI1K & $12.11^{\mathrm{cd}}$ & $12.20^{\mathrm{cd}}$ & $0.50^{\mathrm{a}}$ & $0.49^{\mathrm{ab}}$ & $20.19^{d}$ & $20.11^{c}$ \\
\hline WI3K & $12.02^{\mathrm{cd}}$ & $12.13^{d}$ & $0.48^{\mathrm{ab}}$ & $0.47^{b}$ & $21.21^{c}$ & $21.02^{b}$ \\
\hline WI5K & $11.87^{\mathrm{d}}$ & $11.92^{\mathrm{e}}$ & $0.47^{\mathrm{b}}$ & $0.46^{\mathrm{b}}$ & $21.22^{c}$ & $21.32^{\mathrm{b}}$ \\
\hline WI7K & $11.99^{\mathrm{cd}}$ & $11.86^{\mathrm{e}}$ & $0.48^{\mathrm{ab}}$ & $0.47^{b}$ & $20.11^{d}$ & $21.01^{b}$ \\
\hline SIC & $12.66^{a}$ & $12.65^{\mathrm{a}}$ & $0.40^{\mathrm{cd}}$ & $0.39^{c}$ & $20.21^{d}$ & $21.21^{\mathrm{b}}$ \\
\hline SI1K & $12.54^{\mathrm{ab}}$ & $12.52^{\mathrm{ab}}$ & $0.42^{c}$ & $0.41^{c}$ & $21.63^{b c}$ & $21.33^{b}$ \\
\hline SI3K & $12.32^{\mathrm{abc}}$ & $12.55^{\mathrm{ab}}$ & $0.40^{\text {cd }}$ & $0.42^{c}$ & $21.99^{b}$ & $21.54^{b}$ \\
\hline SI5K & $12.31^{\mathrm{abc}}$ & $12.41^{\mathrm{abc}}$ & $0.41^{\mathrm{cd}}$ & $0.40^{c}$ & $22.23^{b}$ & $22.45^{\mathrm{a}}$ \\
\hline SI7K & $12.23^{b c d}$ & $12.40^{\mathrm{abc}}$ & $0.39^{d}$ & $0.39^{c}$ & $22.85^{a}$ & $22.98^{\mathrm{a}}$ \\
\hline
\end{tabular}

Means followed by the same letter(s) within a separate column are not significantly different at 0.05 level of probability.

\section{Leaf elemental content:}

Table (7) represents the effect of well and stress water irrigation plus kaolin spraying treatments on $\mathrm{N}, \mathrm{P}$ and $\mathrm{K}$ in leaves of "Le-conte" pear trees in 2012 and 2013 seasons. It was obvious from the obtained results that, in general it was found that well irrigated increased N, P and K percentage in "Leconte" pear leaf as compared with stress water treatment. Moreover, the usage of kaolin either with well irrigation or stress irrigation gradually increased N, P and $\mathrm{K}$ percentage as compared with WIC and SIC, also it was found that increasing kaolin concentrations in the two seasons in both well and stress irrigation treatments decreased the N,P and K percentage leaf content. As for nitrogen content, statistical analysis showed that, the highest significant value was obtained by WI1K treatment and the lowest significant value was obtained by SIC in the first season and SI1K in the second season. The differences between WI3K and WI5K also, between SI5K and SI7K were not big enough to be significant in both experimental seasons.

Concerning phosphorus and potassium, the same trend was found, data cleared that, the differences among the treatments (well irrigated with kaolin) WI1K, WI3K, WI5K andWI7K were not big enough to be significant. The lowest value was obtained by SIC in the two minerals for two seasons.

The same trend was found by Glenn et al. (2001), they reported that application of particle films increased the foliage reflectivity and influence on leaf physiology. Romero et al. (2010) found that, The linear relationships between Kroot-stem and Kplant, and $\Psi_{\mathrm{s}}$ suggest that plant hydraulic conductance and root water uptake were progressively reduced during water stress in grapevines, they also found that, the significant decrease in leaf nitrogen observed in regulated deficit irrigation not during the well-irrigated period and reduced $\mathrm{N}$ uptake in deficit- irrigated treatments as a consequence 
of soil water deficit .Also, Stanley (1998) and Schupp et al. (2002), found that increasing the concentrations of kaolin or silica gel decreased the concentrations of N, P and $\mathrm{K}$ contents in leaf and fruit apple.

It was concluded from the previous data that, stress irrigation with kaolin treatments improved fruit set and fruit quality, while well irrigation with kaolin increased average fruit weight and $\mathrm{N}, \mathrm{P}$ and $\mathrm{K}$ percentages.

Table (7): Effect of kaolin applications at well and stress irrigated pear trees on NPK leaf content in 2012 and 2013 seasons

\begin{tabular}{l|cccccc}
\hline \multicolumn{1}{c|}{ Treatments } & \multicolumn{2}{|c}{$\mathrm{N}(\%)$} & \multicolumn{2}{c}{$\mathrm{P}(\%)$} & \multicolumn{2}{c}{$\mathrm{K}(\%)$} \\
\hline & 2012 & 2013 & $2012^{\mathrm{c}}$ & 2013 & $2012^{\mathrm{a}}$ & 2013 \\
\hline WIC & $1.92^{\mathrm{cd}}$ & $1.99^{\mathrm{c}}$ & $0.42^{\mathrm{b}}$ & $0.42^{\mathrm{ab}}$ & $1.39^{\mathrm{b}}$ & $1.36^{\mathrm{b}}$ \\
WI1K & $2.22^{\mathrm{a}}$ & $2.25^{\mathrm{a}}$ & $0.48^{\mathrm{a}}$ & $0.46^{\mathrm{a}}$ & $1.46^{\mathrm{a}}$ & $1.43^{\mathrm{a}}$ \\
WI3K & $2.01^{\mathrm{b}}$ & $2.14^{\mathrm{b}}$ & $0.48^{\mathrm{a}}$ & $0.45^{\mathrm{a}}$ & $1.45^{\mathrm{a}}$ & $1.43^{\mathrm{a}}$ \\
WI5K & $1.99^{\mathrm{bc}}$ & $2.14^{\mathrm{b}}$ & $0.46^{\mathrm{a}}$ & $0.45^{\mathrm{a}}$ & $1.43^{\mathrm{a}}$ & $1.39^{\mathrm{ab}}$ \\
WI7K & $1.92^{\mathrm{cd}}$ & $2.11^{\mathrm{b}}$ & $0.45^{\mathrm{a}}$ & $0.42^{\mathrm{ab}}$ & $1.44^{\mathrm{a}}$ & $1.39^{\mathrm{ab}}$ \\
SIC & $1.72^{\mathrm{f}}$ & $1.94^{\mathrm{d}}$ & $0.30^{\mathrm{d}}$ & $0.33^{\mathrm{d}}$ & $1.30^{\mathrm{b}}$ & $1.29^{\mathrm{c}}$ \\
SI1K & $2.02^{\mathrm{b}}$ & $1.91^{\mathrm{d}}$ & $0.38^{\mathrm{c}}$ & $0.39^{\mathrm{bc}}$ & $1.36^{\mathrm{b}}$ & $1.36^{\mathrm{b}}$ \\
SI3K & $1.92^{\mathrm{cd}}$ & $2.11^{\mathrm{b}}$ & $0.36^{\mathrm{c}}$ & $0.39^{\mathrm{bc}}$ & $1.36^{\mathrm{b}}$ & $1.35^{\mathrm{b}}$ \\
SI5K & $1.85^{\mathrm{de}}$ & $2.01^{\mathrm{c}}$ & $0.36^{\mathrm{c}}$ & $0.38^{\mathrm{bc}}$ & $1.32^{\mathrm{b}}$ & $1.30^{\mathrm{c}}$ \\
SI7K & $1.82^{\mathrm{e}}$ & $2.02^{\mathrm{c}}$ & $0.32^{\mathrm{d}}$ & $0.36^{\mathrm{c}}$ & $1.30^{\mathrm{b}}$ & $1.30^{\mathrm{c}}$ \\
\hline
\end{tabular}

Means followed by the same letter(s) within a separate column are not significantly different at 0.05 level of probability.

\section{REFERENCES:}

Abd El - kader, A.M., M.M.S. Saleh and M.A. Ali. 2006. Effect of soil moisture levels and some antitranspirants on vegetative growth, leaf mineral content, yield and fruit quality of Williams's banana plants. Journal of Applied Science Research, 2(12): 1248-1255.

Abd El-Rhman, I.E.2010.Physiological Studies on Cracking Phenomena of Pomegranates. Journal of Applied Sciences Research, 6(6): 696-703.

Abou-Khaled, A., R.M. Hagan, and D.C. Davenport. 1970. Effects of kaolinite as a reflective antitranspirant on leaf temperature, transpiration, photosynthesis, and water use efficiency. Water Resources Res., 6:280289.

Allen, R.G., L.S. Pereira, D. Raes and M. Smith. 1998. Crop evapotranspiration: guidelines for computing crop water requirements. FAO Irrigation and drainage paper No. 56. Rome, Italy: FAO.

Aly,M.,N.Abd El- Mageed and R.M. Awad. 2010. Reflective particle films affected on sunburn, yield, mineral composition and fruit maturity of Anna apple trees (Malus domestica). Res. J. of Agric. and Biological Sci., 6(1): 84-92.

Association of Official Agricultural Chemist Official Methods of Analysised(A.O.A.C.). 1985.P.O.Box, 450.BenjaminFranklin, Station, Washington. 4: 832. 
Boland, A.M., P.D. Mitchell, P.H. Jerie, and I. Goodwin.1993. The effect of regulated deficit irrigation on tree water use and growth of peach. J. Hort. Sci., 68:261-274.

Boland, A.M., P.H. Jerie, P.D.Mitchell, I.Goodwin, and D.J. Connor. 2000a. Long-term effects of restricted root volume and regulated deficit irrigation on peach: I. nutrition. J. Amer. Soc. Hort. Sci., 125:135-142.

Boland, A.M., P.H. Jerie, P.D.Mitchell, I.Goodwin, and D.J. Connor. 2000b. Long-term effects of restricted root volume and regulated deficit irrigation on peach: II. Productivity and water use. J. Amer. Soc. Hort. Sci., 125:143-148.

Chalmers, D.J., P.D. Mitchell, and L. van Heek. 1981. Control of peach growth and productivity by regulated water supply, tree density and summer pruning. J. Amer. Soc. Hort. Sci., 106: 307-312.

Cooley, N.M., P.R. Clingeleffer, and R.R. Walker. 2004. The balance of berry sugar accumulation, colour and phenolic concentration under deficit irrigation strategies, p. 94-96. In: Blair, R., P.Williams, and S. Pretorious (eds.). Proc. $12^{\text {th }}$ Australian Wine Industry Technical Conference. Melbourne, Australia, Australian Wine Industry Technical Conference Inc., Urrbrae, South Australia.

Cortell, J.M., M. Halbleib, A.V. Gallagher, T.L. Righetti, and J.A. Kennedy. 2005. Influence of vine vigor on grape (Vitis vinifera L. Cv. Pinot Noir) and wine proanthocyanidins. J. Agr. Food Chem., 53:5798-5808.

Davenport, D.C., M.A. Fisher and R.M. Hagan. 1972. Some counteractive effects of antitranspirants. Plant Physiol., 49: 722-724.

Davenport, D.C., K.Urin and R.M. Hagen. 1974. Effect of film antitranspirants on growth. J. Exp.Bot., 25: 410.

David, A. R., D.A. Rosenberger and K. L. VanCamp. 2003.Temperature declines during storms and irrigation may contribute to fire blight infection of pear fruit. Plant Management Network Online. Plant Health Progressdoi:10.1094/PHP-2003-0310-01-RS.

Evenhuis, B.1976.Simplified methods for foliar analysis, VII.International Report, Royal Tropical Institute, Amest.

Evenhuis, B. and B.W. Dewaard. 1980.Principles and practices in plant analysis. FAO Soils Bulletin,38(1): 152-163.

Glenn, D.M., G.J. Puterka, S.R. Drake, T.R. Unruh, P. Baherele, E. Prado, and T. Baugher. 2001. Particle film application influences apple leaf physiology, fruit yield, and fruit quality. J. Amer. Soc., Hort. Sci., 126:175181.

Glenn,D.M.,A. Erez,G.J. Puterka, and P.Gundrum. 2003. Particle films affect carbon assimilation and yield in 'Empire' apple. J. Amer. Soc. Sci. 128:356-362.

Glenn, D. M., C. Nicola, W. Rob, C. Peter and S. Krista.2010.Impact of Kaolin Particle Film and Water Deficit on Wine Grape Water Use Efficiency and Plant Water Relations. HORTSCIENCE, 45(8):1178-1187. 2010.

Glenn, D.M., G.J. Puterka, T. vanderZwet, R.E. Byers, and C. Feldhake. 1999. Hydrophobic particle films: A new paradigm for suppression of arthropod pests and plant disease. J. Econ. Entom. 92:759-771. 
Green, D.M., A. Erez and G.J. Puterka. 2003. Reflective particle films affect photosynthesis and yield in Empire apple. J. of Amer. Soc. for Hort. Sci., 128: 175-181.

Heron, K.I., M. Le Grange, M. Smit, S. Reynolds and G. Jacobs. 2002. Controlling vigour and colour development in the bi- coloured pear cultivar Rosemarie. Acta Hort. (ISHS), 596:753-756.

Jifon, J.L. and J.P. Syvertsen. 2003. Kaolin particle film applications can increase photosynthesis and water use efficiency of 'RubyRed' grapefruit leaves. J. Amer. Soc. Hort. Sci., 128:107-112.

Johnson, R.S., D.F. Handley, and T.M. DeJong 1992. Long-term response of early maturing peach trees to postharvest water deficits. J. Amer. Soc. Hort. Sci., 117:881-886.

Keller, M. 2005. Deficit irrigation and vine mineral nutrition. Am. J. Enol. Vitic., 56:267-283.

Koundouras, S., E. Hatzidimitriou, M. Karamolegkou, E. Dimopoulou, S. Kallithraka, J. T. Tsialtas. 2009.Irrigation and rootstock effects on the phenolic concentration and aroma potential of Vitis vinifera L. cv. " Cabernet Sauvignon" grapes. Journal of Agricultural and Food Chemistry, 57(17): 7805-7813.

Kriedemann, P.E. and I. Goodwin 2003. Irrigation Insites No. 3.Regulated deficit irrigation and partial rootzone drying. Land and Water Australia, ACT, Australia.

Layne, D.R., Z. Jiang and J.W. Rushing. 2002. The influence of reflective film and retain on red skin coloration and maturity of Gala apples. Hort. Tech., 12(4): 640-645.

Lombardini, L., D. M. Glenn, and M. K. Harris. 2004. Application of kaolinbased particle film on pecan trees: consequences on leaf gas exchange stem water potential, nut quality and insect populations. HortScience, 39: 857-858.

Magness, J.R. and C.F. Taylor (1925).An improved type of pressure tester for the determination of fruit maturity.U.S. Dept. Agric. Circ. No. 350, pp. 8.

Masoud A. A. 2012. Impact of Some Antitranspirants on Yield And Fruit Quality of Hamawy Apricot Trees Grown in Sandy Soils. Research Journal of Agriculture and Biological Sciences, 8(2): 78-82, 2012.

McCarthy, M.G., B.R. Loveys, P.R. Dry, and M. Stoll. 2002. Regulated deficit irrigation and partial root zone drying as irrigation management techniques for grapevines. In Deficit Irrigation Practices. FAO Water Reports, No. 22, pp. 79-87. FAO, Rome.

Mitchell, P.D. and D.J.Chalmers. 1982. The effect of reduced water supply on peach tree growth and yields. J. Amer. Soc. Hort. Sci., 107:853-856.

Mitchell, P.D., B. van den Ende, P.H. Jerie, and D.J. Chalmers. 1989. Response of 'Bartlett' pear to withholding irrigation, regulated deficit irrigation, and tree spacing. J. Amer. Soc. Hort. Sci., 114:15-19.

Moriana, A., F. Orgaz, M. Pastor, and E. Fereres. 2003. Yield responses of a mature olive orchard to water deficits. J. Amer. Soc. Hort. Sci., 128:425431.

Murphy, J. and J.P.Riley. 1962. A modified single solution method for the determination of phosphate in natural water. Anal. Chem. Acta, 27: $31-36$. 
Nakano, A. and Y. Uehara. 1996.The Effects of Kaolin Clay on Cuticle Transpiration in Tomato.ActaHorticulturae, 44: 233-238.

Romero,P., J. I. Fernández-Fernández and A. Martinez-Cutillas. 2010. Physiological Thresholds for Efficient Regulated Deficit-Irrigation Management in Winegrapes Grown under Semiarid Conditions. Am. J. Enol. Vitic., 61:300-312.

Rosati, A., S.G. Metcalf, R.P. Buchner, A.E. Fulton, and B.D. Lampinen. 2006. Physiological effects of kaolin applications in well irrigated and water-stressed walnut and almond trees. Ann. Bot. (Lond.) 98:267-275.

Saleh, M.M.S. and M.El-AshrySoad. 2006. Effect of some antitranspirants on leaf mineral content, fruit set, yield and fruit quality of Washington Navel and Succary orange trees. J. of Applied Science Research, 2(8): 486-490.

Schupp, J.R., E. Fallahi and JK-JO Chun. 2002. Effect of particle film on fruit sunburn maturity and quality of 'Fuji' and 'Honeycrisp' apple. HortTechnology, 12(1): 87-90.

Shellie, K. 2006.Vine and berry response of Merlot (Vitis vinifera L.) to differential water stress. Amer. J. Enol. Viticult., 57:514-518.

Showler, A.T. 2002. Effects of kaolin-based particle film application on bollweevil (Coleoptera: Curculionidae) injury to cotton. Journal of Economic Entomology 95: 754-762.

Snedecor, G.W. and Cochran, W.G. 1980. Statistical Methods, 18th ed., Ames, lowa, USA: The lowa State College Press.

Soar, C.J., J. Speirs, S.M. Maffei, and B.R. Loveysm. 2004. Gradients in stomatal conductance, xylem sap $A B A$ and bulk leaf $A B A$ along canes of Vitisvinifera cv. "Shiraz": Molecular and physiological studies investigating their source. Func. Plant Biol., 31:659-669.

Song J., K. C. Shellie, H. Wang and M. C. Qian. 2012. Influence of deficit irrigation and kaolin particle film on grape composition and volatile compounds in Merlot grape (Vitis vinifera L.). Food Chemistry, 134: 841850.

Stanley, D. 1998. Particle films: A new kind of plant protectant. Agr. Res., 46(11):16-19.

Tarara, J.M., J. Lee, S.E. Spayd, and C.F. Scagel. 2008. Berry temperature and solar radiation alter acylation, proportion, and concentration of anthocyanin in Merlot grapes. Amer. J. Enol. Viticult., 59:235-247.

Thomas A.L., M.E. Muller, B.R. Dodson, M.R. Ellersieck and M.Kaps. 2004. A kaolin-based particle film suppresses certain insect and fungal pests while reducing heat stress in apples. Journal of American Pomological Society, 58: 42-51.

Wample, R.L. 1996.Issues in vineyard irrigation. Wine East July-Aug:8-21.

Wand, S.J.E., K.I. Theron and J. Ackerman. 2006. Harvest and post harvest apple fruit quality following applications of Kaolin particle film in South Africa orchards. Scientia Hort., 107: 271-276.

Yang, X. 1995.Effect of antitranspirants on growth and development of apple trees. J. of Gansu Agric. Univ.,pp: 100-110. 


\section{الملخص العربي \\ تأثير إضافة الكاولين مع الري الجيا والاجهاد المائي على بعض قياسات النمو، المحصول وجودة الثمار في أشجار الكمثرى صنف ليكونت}

\section{ريحاب محمد عوض}

قسم الانتاج النباتى - كلية الزراعه- سابا بانشا- جامعة الاسكندريه

أجريت هذه التجربة خلال موسمي 2012 و2013 على اشجار الكمثى صنف ليكونت. وقد تم إضافة

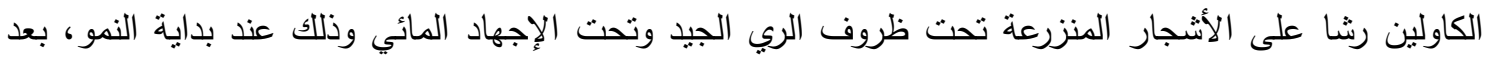

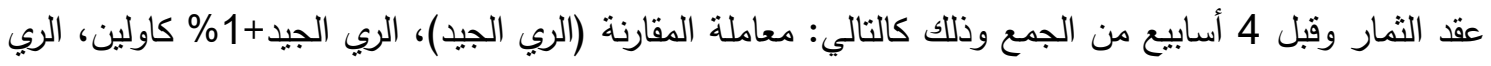

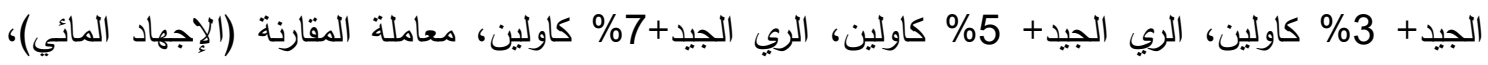

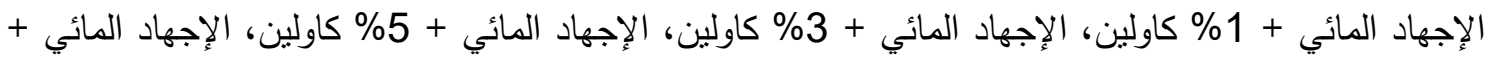

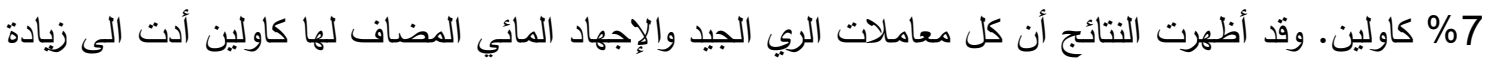
طول النمو وذلك بالمقارنة بمعاملتي الكونترول. وقد أعطت معاملتيالإجهاد المائي + 3و كانئ كاولين، الإجهاد المائي

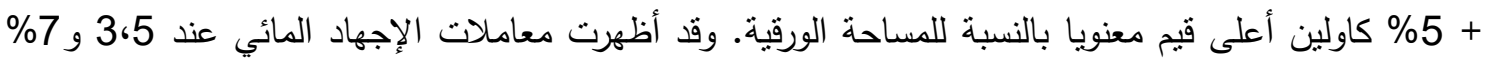
رشا بالكاولين زيادة معنوية في النسبة المئوية لعقد الثمار كما أدت الى خفض النسبة المئوية لتساقط الثمار وذلك الكئك

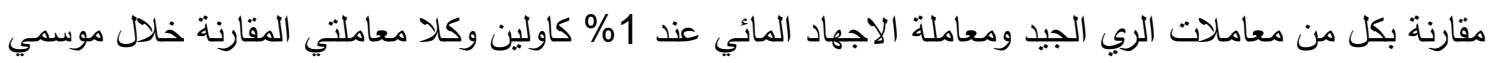

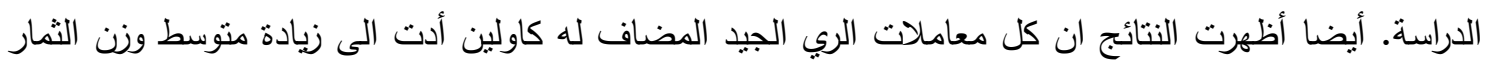

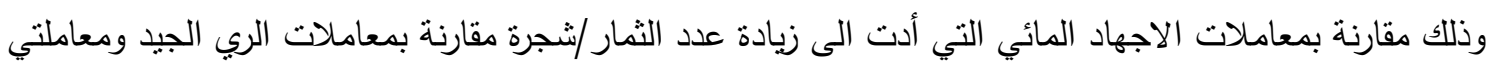
المقارنة خلال موسمي الدراسة. وقد أظهرت معاملة المقارنة للاجهاد المائي أعلى معنويه بالنسبه للمواد الصلبه الكليه مقارنة بمعاملات الرى الجيد و معاملة المقارنه. كل معاملات الاجهاد المائى ادت الى خفض الى النسبه المئويه

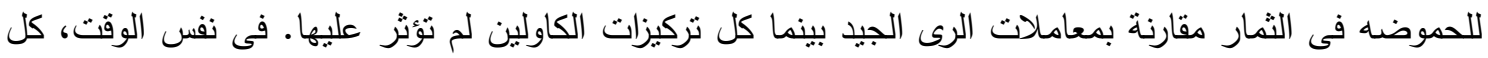

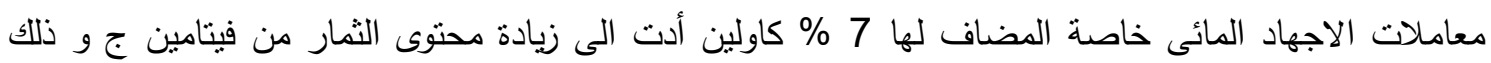

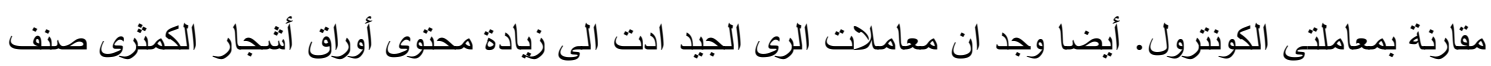
ليكونت من النسبه المئويه لكل من النيتروجين و الفسفور و البوتاسيوم و ذلك مقارنة بمعاملات الاجهاد المائى. 
